\title{
Modern adhesive systems. Comparative study on adhesion in dental tissues
}

\author{
Sisteme adezive moderne. Studiu comparativ privind \\ adeziunea la ţesuturile dentare
}

\author{
Bogdan Mihai Gălbinaşu', Teodor Alexandru Păunescu², Mihai Ghiță³, Ion Pătraşcu' \\ ${ }^{1}$ Catedra de Tehnologia Protezelor şi Materiale Dentare, Facultatea de Medicină Dentară, \\ Universitatea de Medicină şi Farmacie „Carol Davila“, Bucureşti, România \\ ${ }^{2}$ Cabinet stomatologic, Râmnicu Vâlcea, România \\ ${ }^{3}$ Institutul Naţional de Cercetare-Dezvoltare pentru Metale Neferoase şi Rare, Pantelimon, România
}

\begin{abstract}
Aim. The aim of this study is to evaluate the interface between resin and hard dental tissues obtained by using two adhesive systems.

Material and method. Ten extracted human molars were bonded using a total etch adhesive (Adper Single Bond 2, 3M ESPE) and a self-etching agent (Futurabond U DC, VOCO), after artificially preparing MOD cavities on them. The composite build ups were constructed using Filltek Z550 nanohybrid composite from 3M ESPE. Teeth were embedded in epoxy resin, using special vacuum equipment, then metallographic grinded to a certain point of interest and polished. The samples were analyzed using a Carl Zeiss Optical Microscope (Axio Imager $\mathrm{A} 1 \mathrm{M})$ and the image acquisition was made using a dedicated microscope camera (Canon Powershot A640) and dedicated software (Axio Vision).

Results. Resin-enamel bonds were uniform over the entire surface on both adhesive systems whereas resinden-tin bonds resulted using the total etch system are of inferior quality (there are micro spaces between dentin and resin that range from $6,18 \mu \mathrm{m}$ to $24,12 \mu \mathrm{m}$ ) than the ones resulted using the self-etch adhesive, in which case the bonds were uniform and well adapted with no signs of micro spaces.

Conclusions. Resin-dentin bonds resulted using a total etch adhesive may reduce the quality of the restoration, thus being susceptible to marginal infiltration and debonding over time.
\end{abstract}

Keywords: dentin, enamel, self-etch, total etch, bonding, microscope

\section{REZUMAT}

Scop. Scopul acestui studiu este de a evalua interfaţa dintre răşină şi ţesuturile dure dentare, obţinută utilizând două sisteme adezive diferite.

Materiale şi metodă. Au fost create cavităţi MOD pe zece molari umani extraşi. Pe cinci dintre aceştia s-a aplicat un sistem adeziv total etch (Adper Single Bond 2, 3M ESPE), iar pe ceilalţi un adeziv self-etch (Futurabond DC, VOCO). Dinţii au fost apoi obturaţi folosind un compozit nanohibrid (Filltek Z550 de la 3M ESPE). În etapa următoare au fost înglobaţi în răşină epoxidică, folosind un aparat de înglobare în vid. Au fost şlefuiţi metalografic până la nivelul zonei de interes şi lustruiţi. Probele obţinute au fost analizate cu ajutorul unui microscop optic (Carl Zeiss Axio Imager A1M). Achiziţia şi prelucrarea imaginilor au fost făcute prin intermediul unei camere şi al unui soft dedicat microscopului optic.

Rezultate. Interfaţa răşină-smalţ este uniformă pe toată suprafaţa de contact în cazul ambelor sisteme adezive, însă interfaţa răşină-dentină în cazul probelor la care a fost utilizat adezivul total etch este de o calitate inferioară, prezentând microspaţii ce variază între $6,18 \mu \mathrm{m}$ şi $24,12 \mu \mathrm{m}$, spre deosebire de interfaţa rezultată în cazul sistemului self-etch, unde există o adeziune bună, fără microspaţii.

Concluzii. Adeziunea răşină-dentină obţinută prin utilizarea adezivilor total etch este susceptibilă microinfiltraţiilor şi apariţiei leziunilor carioase secundare.

Cuvinte cheie: dentină, smalţ, self-etch, total etch, bonding, microscop

\section{INTRODUCERE}

Stomatologia adezivă reprezintă o bună parte din munca efectuată de medicul stomatolog în cabi- netul dentar. Există numeroase discuții şi studii realizate pentru a defini materialele optime utilizării în diverse situații clinice. 
Evoluția materialelor (1) şi a tehnicilor adezive (2) a venit în sprijinul medicului dentist, oferind posibilitatea tratării chiar şi a celor mai dificile cazuri, unde stomatologia convențională ar fi eşuat. Actualmente, cei mai folosiți adezivi dentari sunt cei total-etch, însă cei self-etch încep să câştige popularitate. Înaintea utilizării unui adeziv total-etch, suprafețele amelare şi dentinare trebuie condiționate prin aplicare de acid ortofosforic $30-40 \%$ (3) pentru 15-30 de secunde, variind în funcție de tehnica utilizată. Acest lucru duce de multe ori la apariția unei discrepanțe între profunzimea demineralizării şi cea a infilttrării monomerului, fapt tradus clinic prin apariția unei sensibilităţi postoperatorii (4). Atunci când se utilizează un sistem self-etch, nu mai este necesară gravare acidă separată, astfel profunzimea demineralizării este egală cu cea a infiltrării răşinice (5).

Scopul acestui studiu este de a analiza comparativ interfața adezivă obținută prin utilizarea unui adeziv total-etch şi a unui adeziv self-etch.

\section{MATERIALE ŞI METODĂ}

În cadrul acestui studiu s-au folosit 10 molari umani extraşi, păstrați în apă distilată, la temperatura camerei, reîmprospătată la fiecare 7 zile. Am preparat cavități MOD cu ajutorul unor freze diamantate conectate la o turbină dentară răcită cu apă. Cei 10 molari au fost împărțiți în doua grupe a câte 5 dinți, una pentru sistemul total etch (Adper Single Bond 2, 3M ESPE) şi una pentru sistemul self-etch (Futurabond U DC, VOCO). Adezivii au fost aplicați conform specificațiilor producătorilor (Tabelul 1).

Construcția restaurărilor a fost făcută cu ajutorul unui compozit nanohibrid de la firma $3 \mathrm{M}$ ESPE (Filltek Z550), în straturi de $2 \mathrm{~mm}$ grosime. Fiecare strat a fost polimerizat timp de 40 de secunde, sursa de lumină fiind orientată dinspre pereții cavităților. După etapa restaurativă, dinţii au fost depozitaţi în apă distilată, la temperatura camerei, timp de o săptămână. A urmat apoi faza de înglobare a dinților, pentru care am utilizat o răşină epoxidică (Epothin 2 - Buehler), conformatoare şi un aparat de înglobare în vid (Cast N' Vac - Buehler). Priza finală a răşinei a fost la 24 de ore. În vederea analizei microscopice, probele au fost şlefuite metalografic şi lustruite cu ajutorul unui aparat de şlefuit şi lustruit de la Buehler, folosind hârtii abrazive de carbură de siliciu, de granulații diferite (de la grosieră la fină), la o viteză de $300 \mathrm{rpm}$. Probele astfel obținute au fost lustruite cu ajutorul unei pâsle de microfibră (Microcloth, PSA, 10 in) pe care s-a aplicat suspensie de alumină de $0,05 \mu \mathrm{m}$. Un exemplu de probă poate fi observat în Figura 1.

$\mathrm{Cu}$ ajutorul unui microscop mineralogic cu lumină polarizată şi reflectată (Carl Zeiss Axio Imager A $1 \mathrm{~m}$ ), am baleiat probele, folosind lentile $10 \mathrm{x}$ (magnificare 90). Am realizat achiziția de imagini cu ajutorul unei camere dedicate microscopului optic, iar prelucrarea şi măsurarea acestora cu ajutorul unui software dedicat (Axio Vision, release 4.8). De asemenea, am folosit o bară de măsură etalonată, erorile de măsurare fiind de maximum $1 \mathrm{~mm}$.

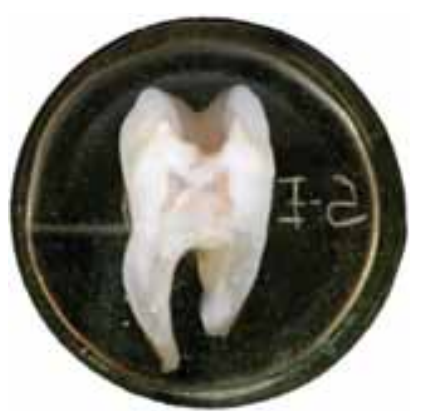

FIGURA 1. Exemplu de probă

TABELUL 1. Materiale folosite, componente, paşi de aplicare, producători

\begin{tabular}{|c|c|c|c|}
\hline Material & Componente & Pași de aplicare & Producător \\
\hline Single Bond 2 & $\begin{array}{l}\text { BisGMA, HEMA, dimetilacrilați, etanol, } \\
\text { apă, un sistem de foto-inițiere, copolimeri } \\
\text { funcționali metacrilici ai acizilor poliacrilic } \\
\text { și poliitaconic și nano-umplutură de siliciu }\end{array}$ & $\begin{array}{l}\text { 1. Toaleta cavității; } \\
\text { 2. Demineralizare acidă timp de } 15 \mathrm{~s} \text {; } \\
\text { 3. Spălarea acidului timp de } 10 \mathrm{~s} ; \\
\text { 4. Îndepărtarea excesului de apă; } \\
\text { 5. Aplicarea Single Bond } 2 \text { timp de } 15 \mathrm{~s} \text {; } \\
\text { 6. Uscare cu jetul de aer timp de } 5 \mathrm{~s} \text {; } \\
\text { 7. Fotopolimerizare timp de } 10 \mathrm{~s} \text {. }\end{array}$ & $\begin{array}{l}\text { 3M ESPE, St. Paul, } \\
\text { MN, USA }\end{array}$ \\
\hline $\begin{array}{l}\text { Futurabond U, } \\
\text { Mono-Doză }\end{array}$ & $\begin{array}{l}\text { 2-hidroxietil metacrilat, BisGMA, HEMA, } \\
\text { monomer adeziv acid, uretan dimetacrilat } \\
\text { și un catalizator }\end{array}$ & $\begin{array}{l}\text { 1. Toaleta cavității; } \\
\text { 2. Aplicarea Futurabond U timp de } 20 \mathrm{~s} \text {; } \\
\text { 3. Uscare cu jetul de aer timp de } 5 \mathrm{~s} \text {; } \\
\text { 4. Fotopolimerizare timp de } 10 \mathrm{~s} \text {. }\end{array}$ & $\begin{array}{l}\text { VOCO Gmbh, } \\
\text { Cuxhaven Germany. }\end{array}$ \\
\hline
\end{tabular}




\section{REZULTATE}

În urma analizei microscopice, am obținut 10 micrografii, 5 pentru grupul total etch şi 5 pentru grupul self etch. Interfața răşină-smalț este uniformă la nivelul întregii suprafețe examinate a ambelor grupe de probe. Diferențe notabile se regăsesc însă la nivelul interfeței răşină-dentină între grupul total-etch şi cel self-etch. Micrografiile din grupul total-etch se pot observa în Figurile 2-6, iar cele din grupul self-etch în Figurile 7-11.

Interfaţa răşină-dentină este neuniformă pe toată suprafața examinată a grupului total-etch. Se pot observa microspații la toate probele din acest grup, microspații ce variază între $6,18 \mu \mathrm{m}$ şi $24,12 \mu \mathrm{m}$. Comparativ, interfața răşină-dentină examinată la grupul self-etch este mai uniformă, cu lipsa unor microspaţii măsurabile. La nivelul unei singure probe din acest grup am putut identifica şi măsura microspațieri, însă, şi în acest caz, ele sunt mai reduse față de cele din grupul total-etch, având valori cuprinse între $5,17 \mu \mathrm{m}$ şi $18,78 \mu \mathrm{m}$.

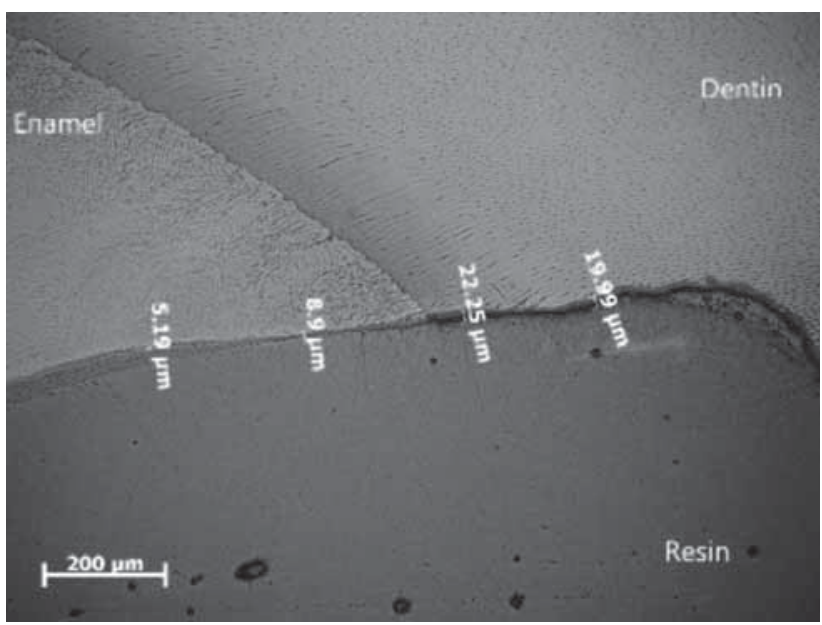

FIGURA 2. Total-etch - proba 1

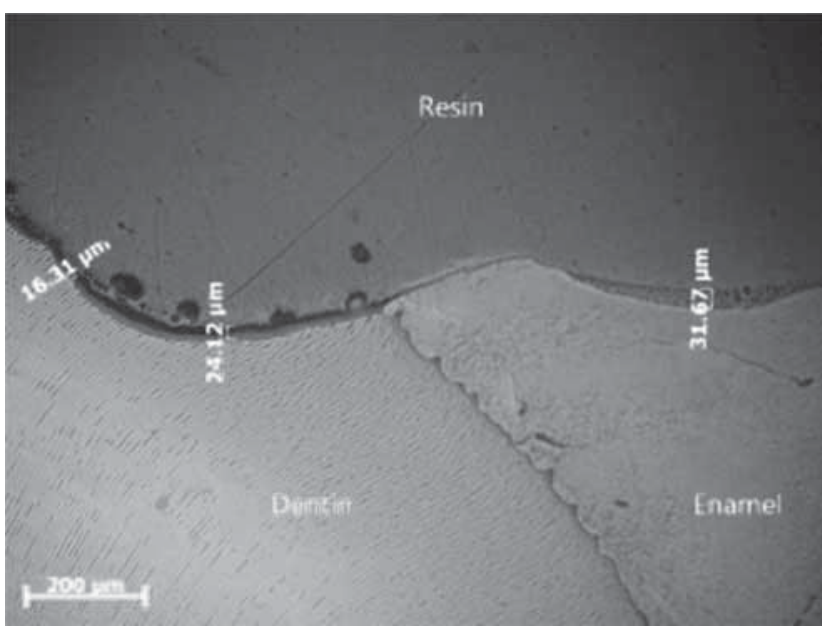

FIGURA 3. Total-etch - proba 2

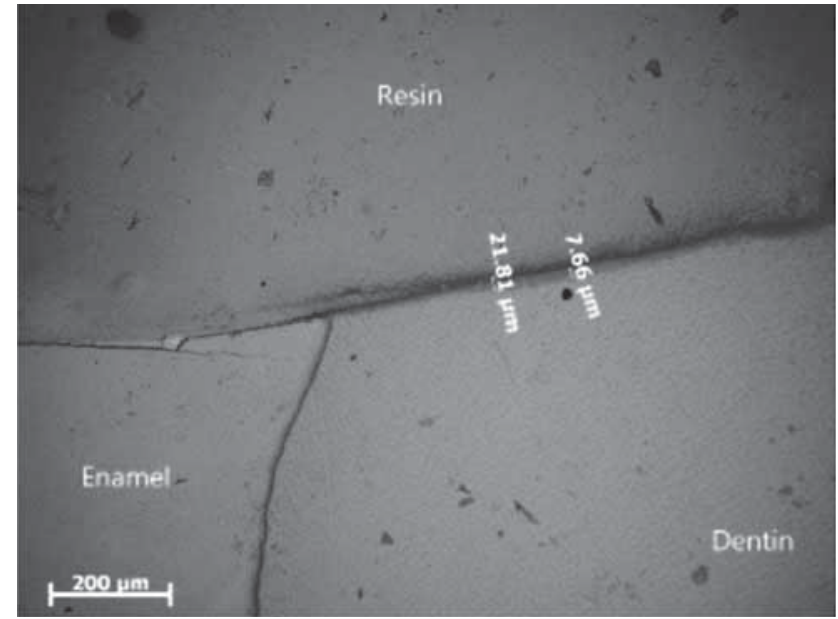

FIGURA 4. Total-etch - proba 3

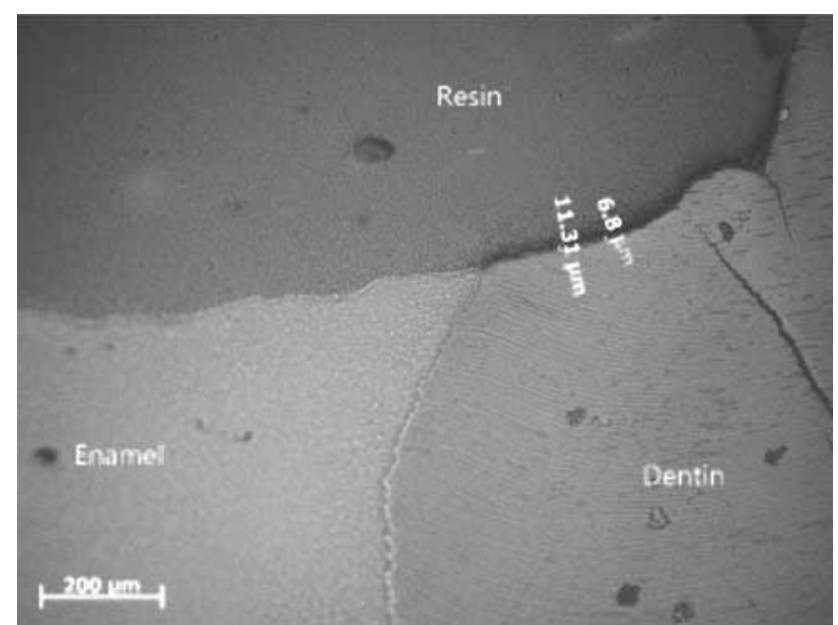

Figura 5. Total-etch - proba 4

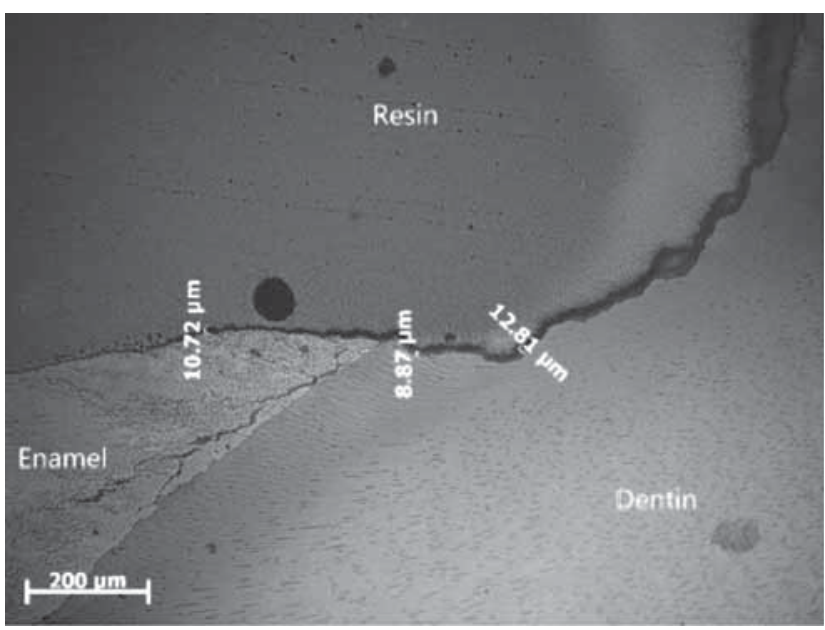

Figura 6. Total-etch - proba 5 


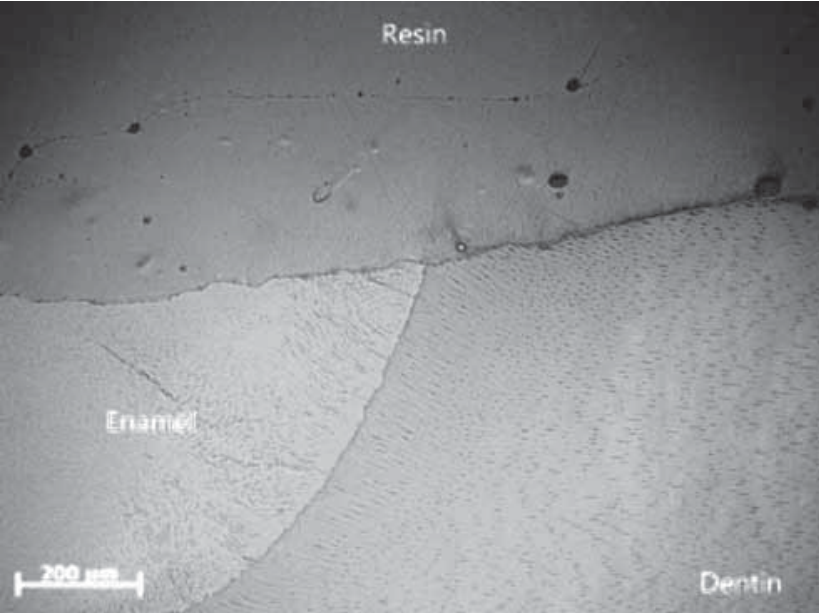

FIGURA 7. Self-etch - proba 1

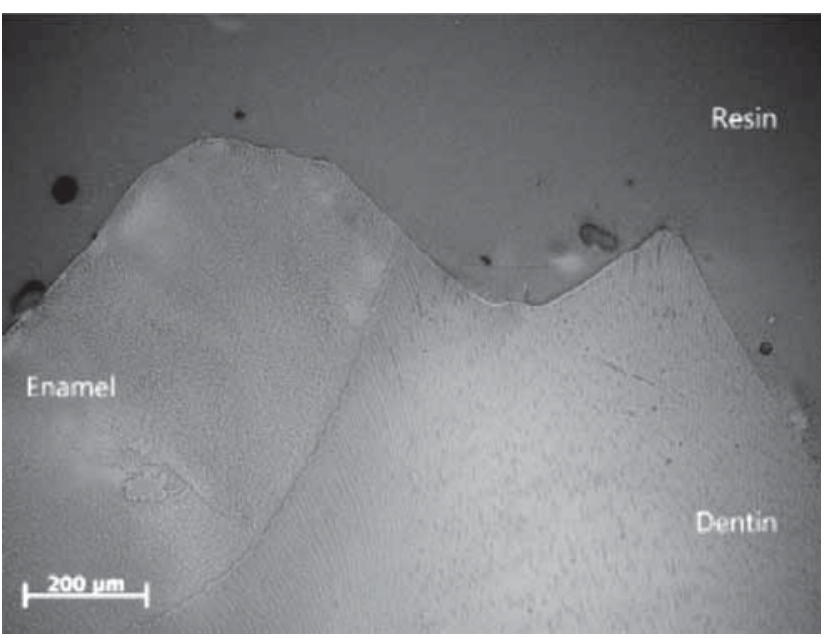

FIGURA 9. Self-etch - proba 3

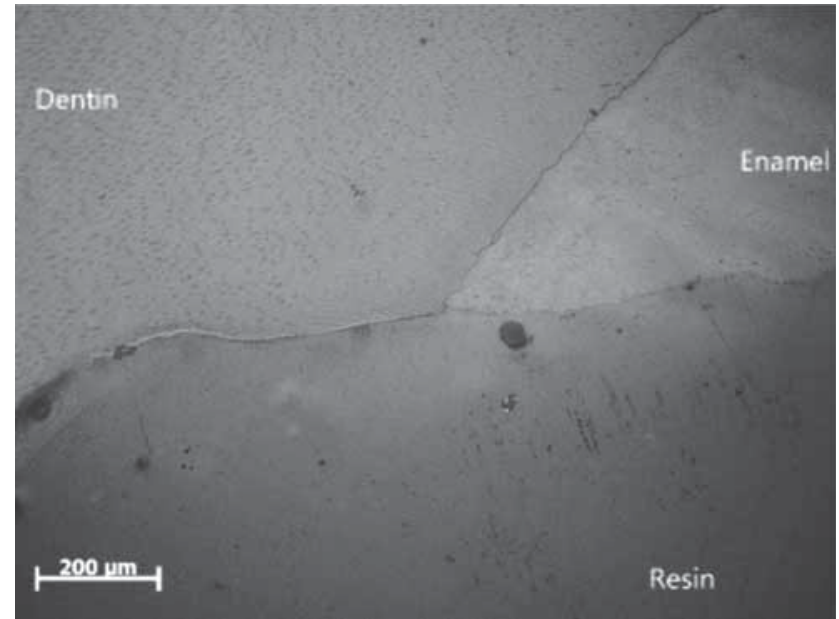

FIGURA 8. Self-etch - proba 2

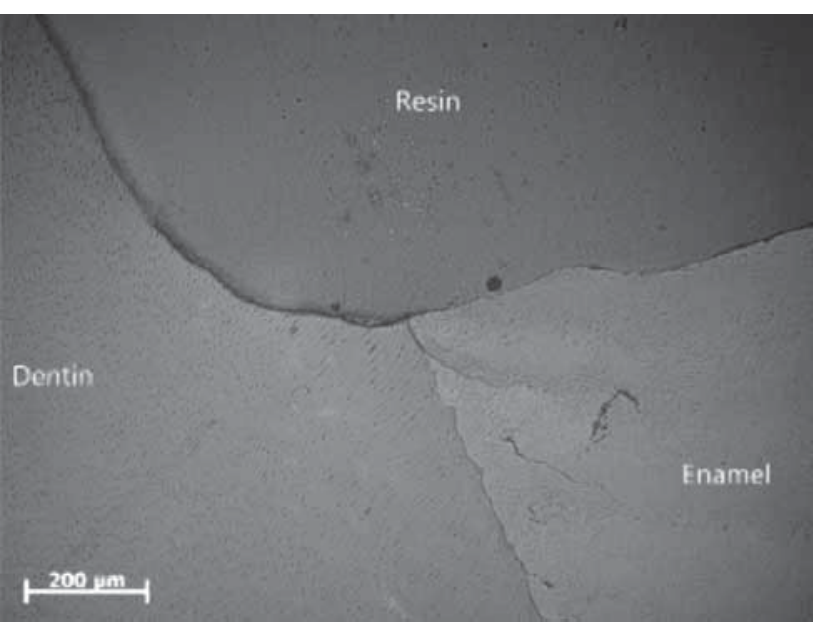

FIGURA 10. Self-etch - proba 4

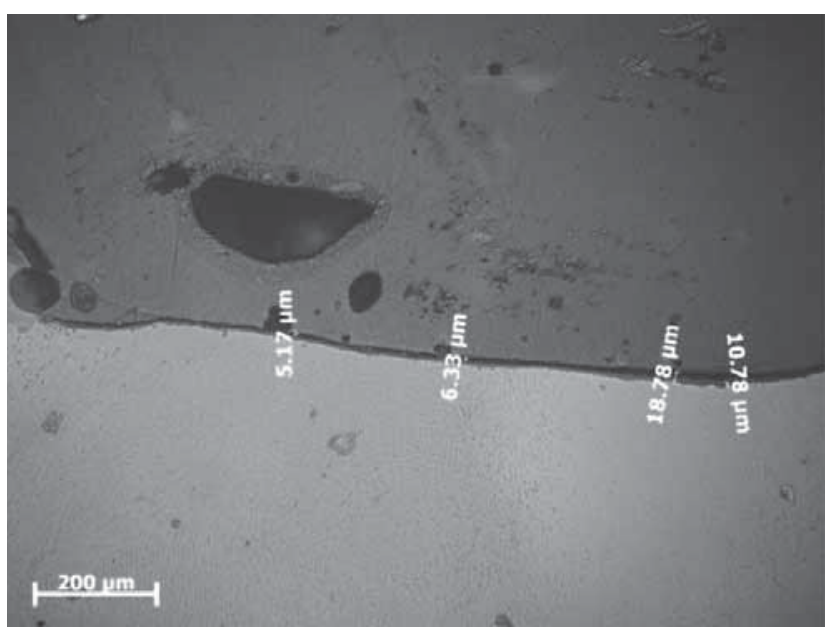

FIGURA 11. Self-etch - proba 5

\section{DISCUTुII}

În momentul de față, în majoritatea cabinetelor dentare predomină utilizarea sistemelor adezive total-etch, numeroşi medici dentişti fiind reticenţi în privinţa adezivilor self-etch. Deşi există numeroase studii $(8,9,10)$ asupra acestor sisteme adezive, ce le atestă atât calităţile, cât şi minusurile, utilizarea lor este în continuare redusă. Acest lucru se datorează în special obişnuinţei de lucru şi a rezultatelor obținute cu ajutorul sistemele adezive convenționale, dar şi concepției privind superioritatea adeziunii prin utilizarea unei etape separate de gravare acidă. 
Totuşi, sistemele adezive self-etch îşi găsesc utilitatea mai ales în situațiile în care realizarea izolării dentare este dificilă, întrucât etapele şi timpul de lucru sunt reduse, oferind posibilitatea obținerii adeziunii în condiții mai dificile. De asemenea, aceste sisteme sunt asociate cu o sensibilitate postoperatorie scăzută, putând fi utilizate şi în cavități profunde, fără a irita organul pulpar, datorită agresivității lor mai reduse comparativ cu metoda convenţională de gravare acidă. Deşi aceste sisteme nu ating valorile adezive ale sistemelor etch-and-rinse (7), ele asigură premisele unor restaurări de calitate.

\section{CONCLUZII}

Atunci când se utilizează o tehnică total-etch, avem de parcurs mai multe etape de lucru, fapt ce impune o izolare mult mai riguroasă a dintelui la nivelul căruia se efectuează manopera terapeutică. Aplicarea unui agent demineralizant (în cazul acestui studiu - acid ortofosforic $37 \%$ ) la nivelul țesuturilor dure dentare depăşeşte abilitatea de penetrare a sistemului adeziv la nivelul microretenţiilor astfel formate, rezultând spațieri între țesut şi materialul restaurativ. Din cauza existenței acestor microspații la nivelul interfeței răşină-dinte, aceste restaurări sunt predispuse infiltrației marginale şi deci pierderii fenomenului de adeziune, cu apariția leziunilor carioase secundare. Totodată, acțiunea mult mai profundă a agentului demineralizant poate însemna şi o sensibilitate postoperatorie crescută.

Prin folosirea unui sistem adeziv self-etch se reduc etapele de lucru, rezultând o economie de timp utilă mai ales în situaţiile în care izolarea dentară ridică probleme. De asemenea, uşurința de lucru pe care o prezintă aceste sisteme, mai ales cele all-inone, asigură premisele unor restaurări de calitate, predictibile, întrucât şansa apariţiei unei erori de tehnică este redusă la minimum. Existența sistemelor adezive self-etch sub formă capsulată, de tip monodoză, aduce un plus de ergonomie manoperei clinice, fiind uşor de utilizat şi totodată asigurând un factor în plus de protecție împotriva contaminării încrucişate în cadrul colectivului medic-asistentă-pacient. La aceste sisteme, gradul de penetrare al adezivului este egal cu cel de demineralizare, asigurând astfel o legătură strânsă cu substratul şi o interfață uniformă, atât la nivelul smalțului, cât şi la nivelul dentinei. Sistemele adezive self-etch actuale reprezintă o alternativă foarte bună la tehnicile clasice de gravare acidă separată, generând rezultate promițătoare.

Conflict of interest: none declared Financial support: none declared

\section{BIBLIOGRAFIE}

1. Buonocore MG. A simple method of increasing the adhesion of acrylic filling materials to enamel surfaces. J Dent Res. 1955 Dec;34(6):849-53.

2. Ronald Sakaguchi, Jack Ferracane, John Powers. Craig's restorative dental materials. Philadelphia: Elsevier Mosby, 2011.

3. Ulrike B. Fritz, Peter Diedrich, Werner J. Finger. Self-Etching Primers - an Alternative to the conventional acid etch technique? 2000, Journal of Orofacial Orthopedics.

4. Fernanda B., Francine C. Madruga, Emilia Prochnow, Giana S.Lima, Fabrizio A. Ogliari, Evandro Piva, Rafael R. Morares. Effect of acidic monomer concentration on the dentin bond stability of self-etch adhesives. 2011, International Journal of Adhesion \& Adhesives, pg. 571-574.

5. Manuel Toledano, Raquel Osorio, Alberto Albaladejo, Fatima S. Aguilera, Estrella Osorio. Differential effect of in vitro degradation on resin - dentin bonds produced by self-etch versus total-etch adhesives. 2006, Wiley InterScience.
6. Inoue S, Van Meerbeek B, Vargas M, Yoshida Y, Lambrechts P, Vanherle G. Adhesion mechanisms of self-etching adhesives. Am J Dent, 1999, pg. 131-175.

7. Inoue $S$, Vargas M, Abe $Y$, Yoshida $Y$, Lambrechts $P$, Vanherle $G$ et al. Microtensile bond strength of eleven contemporary adhesives to dentin. J Adhes Dent, 2001, pg. 237-245.

8. Kanca J. Effect of resin primer solvents and surface wetness on resin composite bond strength to dentin. Am J Dent, 1992, pg. 213-215.

9. Yoshida Y Nagakane K, Fukuda R, Nakayama Y, Okazaki M, Shintani $\mathrm{H}$ et al. Comparative study on adhesive performance of functional monomers. J Dent Res. 2004 Jun;83(6):454-8.

10. Yoshida Y, Van Meerbeek B, Nakayama Y, Snauwaert J, Hellemans L, Lambrechts $P$ et al. Evidence of chemical bonding at biomaterial - hard tissue interfaces. J Dent Res, 2000, pg. 709-714. 